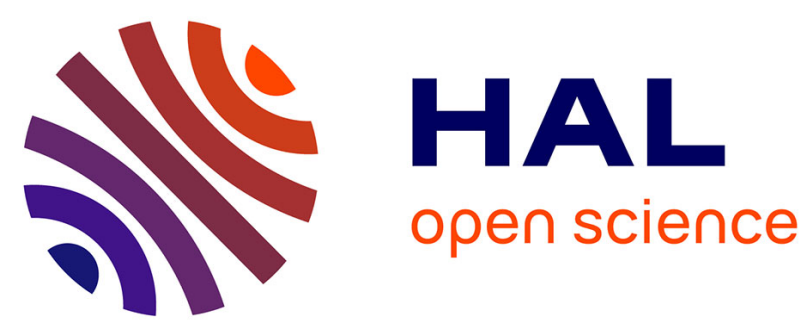

\title{
Local Strain In A 5 - Harness Satin Weave Composite Under Static Tension: Part Ii - Meso-Fe Analysis
}

S. Daggumati, W. van Paepegem, J. Degrieck, T. Praet, B. Verhegghe, J. Xu, S.V. Lomov, I. Verpoest

\section{- To cite this version:}

S. Daggumati, W. van Paepegem, J. Degrieck, T. Praet, B. Verhegghe, et al.. Local Strain In A 5 - Harness Satin Weave Composite Under Static Tension: Part Ii - Meso-Fe Analysis. Composites Science and Technology, 2011, 10.1016/j.compscitech.2011.03.020 . hal-00758606

\section{HAL Id: hal-00758606 https://hal.science/hal-00758606}

Submitted on 29 Nov 2012

HAL is a multi-disciplinary open access archive for the deposit and dissemination of scientific research documents, whether they are published or not. The documents may come from teaching and research institutions in France or abroad, or from public or private research centers.
L'archive ouverte pluridisciplinaire HAL, est destinée au dépôt et à la diffusion de documents scientifiques de niveau recherche, publiés ou non, émanant des établissements d'enseignement et de recherche français ou étrangers, des laboratoires publics ou privés. 


\section{Accepted Manuscript}

Local Strain In A 5 - Harness Satin Weave Composite Under Static Tension:

Part Ii - Meso-Fe Analysis

S. Daggumati, W. Van Paepegem, J. Degrieck, T. Praet, B. Verhegghe, J. Xu, S.V. Lomov, I. Verpoest

PII:

S0266-3538(11)00134-5

DOI:

10.1016/j.compscitech.2011.03.020

Reference:

CSTE 4962

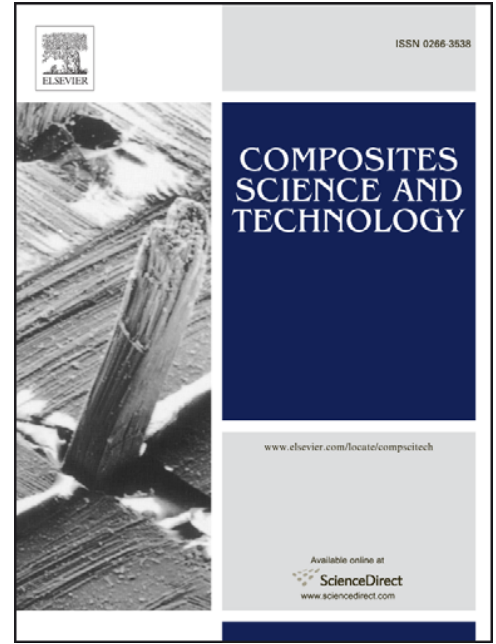

To appear in:

Composites Science and Technology

Received Date:

9 September 2010

Revised Date:

26 March 2011

Accepted Date:

30 March 2011

Please cite this article as: Daggumati, S., Van Paepegem, W., Degrieck, J., Praet, T., Verhegghe, B., Xu, J., Lomov, S.V., Verpoest, I., Local Strain In A 5 - Harness Satin Weave Composite Under Static Tension: Part Ii - Meso-Fe Analysis, Composites Science and Technology (2011), doi: 10.1016/j.compscitech.2011.03.020

This is a PDF file of an unedited manuscript that has been accepted for publication. As a service to our customers we are providing this early version of the manuscript. The manuscript will undergo copyediting, typesetting, and review of the resulting proof before it is published in its final form. Please note that during the production process errors may be discovered which could affect the content, and all legal disclaimers that apply to the journal pertain. 


\title{
LOCAL STRAIN IN A 5 - HARNESS SATIN WEAVE COMPOSITE
}

\section{UNDER STATIC TENSION: PART II - MESO-FE ANALYSIS}

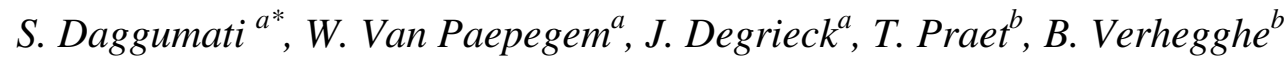

$$
\text { J. Xu }{ }^{c}, \text { S.V. } \text { Lomov }^{c}, \text { I. Verpoest }{ }^{c}
$$

${ }^{a}$ Ghent University, Dept. of Materials Science and Engineering, Sint-Pietersnieuwstraat 41,B-9000 Gent, Belgium

${ }^{b}$ Ghent University, IbiTech-bioMMeda, Campus Heymans-Block B, De Pintelaan 185, B9000 Gent, Belgium

${ }^{c}$ Katholieke Universiteit Leuven, Department of Metallurgy and Materials Engineering, Kasteelpark Arenberg 44, B-3001 Leuven, Belgium

\begin{abstract}
This paper presents the local strain analysis in a thermoplastic 5-harness satin weave composite under uni-axial static tensile load using meso-FE simulations. In order to predict the local strain profiles as observed in the experiments (Part I) at various locations of the composite, different unit cell stacking models with appropriate boundary conditions are used for the FE analysis. Apart from the calculation of local strain values at different locations (inside / traction free surface) of the composite laminate, the aim of the numerical simulations is to understand the 'shadowing' effects of the internal ply shifting on the surface strain behaviour of a 5-harness satin weave composite. Comparison of the experimental local strain values (Part I) at various locations of the satin weave composite reveals that the effects of local yarn constraints are negligible on the local longitudinal strain behavior of the composite.
\end{abstract}

\footnotetext{
*Corresponding author. Tel.: +32 926433 17; fax: +32 92643587 .

E-mail address: Subbareddy.Daggumati@ugent.be
} 
However, local stress-strain profiles obtained from unit cell meso-FE simulations indicate that the longitudinal strain and the transverse stress distribution in the weft yarn at the yarn crimp location is sensitive to the unit cell stacking as well as to the applied boundary conditions to the unit cell.

Keywords: A. Textile composites; D. Local strain analysis; D. Meso-FE modeling; D. embedded sensors; D. Digital image correlation

\section{Introduction}

From the analysis of the heterogeneous strain fields in textile composites, recent publications [1-3] underscore the importance of the accurate prediction of local strain profiles and the corresponding spatial strain distribution. Based on the evaluation of local strain profiles and gradients, reliable predictions of the damage initiation and strength can be accomplished. In this regard, developing a unit cell computational model which can predict the local strain profiles as observed in the experiments can be a challenging task. Previous research work [4-6] in this area dealt with the FE analysis of a single unit cell using infinite laminate boundary conditions. However, comparison of the experimental strain profiles with the meso-FE strain profiles [1, 2, 7-9] leads to the conclusion that it is difficult to achieve an exact correspondence between the ideal unit cell computational stress-strain profiles compared to the shifted (nested) and more complicated composite laminates used in the experimental analysis. 
In the process of improving the traditional unit cell FE simulations, Owens et al. [10] accomplished the unit cell FE analysis using finite and infinite laminate conditions. The above mentioned work concludes that there is a substantial difference in the stress distribution between the laminate outer and inner layers. Moreover, finite and infinite laminate unit cell FE analysis by Ivanov et al. [11] leads to the conclusion that local stress-strain patterns in a textile composite unit cell depend on: 1) yarn placement in the unit cell [4]; 2) number of plies in the laminate; 3) stacking sequence (internal yarn nesting). In addition, conventional meso-FE analysis employs boundary conditions to the unit cell of a textile composite on the assumption of periodicity in the thickness direction. In this case, the stress (strain) concentration can be drastically underestimated, especially in the outer plies. From the experimental local strain analysis of a controlled stacked (inphase) plain weave laminate, Lee et al. [12] concluded that the yarn undulation (yarn crimp) effects are smoothened for the laminate inner layers compared to the surface layers, indicating the possible difference in strain profiles inside the laminate compared to the traction free surface.

Based on the above observations from the literature, detailed local strain analysis in the plies of a 5-harness satin weave composite is accomplished using the unit cell FE simulations as outlined in the current section: 1) computation of the local strain profiles inside the laminate is accomplished with the well established meso-FE procedure i.e. single unit cell with 3D PBCs (Periodic Boundary Conditions). 
Later, the computed numerical strain profiles are compared to the fibre optic local strains obtained from the laminate inner layers (Part I);2) in order to compute the surface strain profiles, initially, single unit cell with in-plane PBCs is used for the FE analysis. However, comparison of the single unit cell FE strain profiles and contours to the surface strain measurements obtained from the digital image correlation (DIC) reveals that neither 3D PBCs nor in-plane PBCs applied to the single unit cell are capable of capturing the local surface strain behaviour both qualitatively (spatial strain distribution) and quantitatively (local strain values) comparable to the DIC strain results.

In order to capture the 'shadowing' effects caused by internal ply shift of the beneath layers on the surface strain pattern, different unit cell stacks were created as explained in [13]. The aforementioned study shows that the increase in tension / bending coupling effects at the yarn crimp location for different ply stacking configurations will reduce the effective elastic modulus. And the order of the calculated numerical effective elastic constants for different unit cell stacking configurations in the ascending order is as follows: "cross-ply > random phase stacking $>$ out-of-phase stacking $>$ iso-phase stacking $>$ single lamina". Based on the above conclusions, instead of computing the surface strain profile using infinite laminate conditions, different unit cell stacks were created with various local ply configurations. 
The underlying principle in the FE analysis of the unit cell stacks with various ply configurations relies on the fact that, by allowing or constraining the yarn undulation in different degrees at the yarn crimp location, FE analysis of the different unit cell stacks combined with appropriate boundary conditions provides an insight into the variation of the local strain values in a carbon-PPS 5-harness satin weave composite. In addition, variations in maximum and minimum strain locations can be determined at different locations of the unit cell.

\section{FE local strain analysis and comparison with the experimental results}

\subsection{Local strain analysis inside the laminate}

In order to start the meso-FE simulations, construction of the unit cell geometrical model and translation into FE mesh is accomplished as explained in [14] and briefly described as follows : 1) variation of the internal yarn dimensions in the 5-satin weave composite is quantified using the micro-CT analysis; 2) along with the carbon fibre data, the obtained textile parameters from the micro-CT measurements (Table 1) are used as an input to the unit cell geometrical modeler software 'WiseTex' [6, 15]; 3) finally, the 'WiseTex' generated unit cell geometrical model is translated into FE mesh and filled with the matrix mesh in the 'MeshTex' software [6]. 
The 'MeshTex' generated unit cell FE model in the form of nodal and element information is transferred to the commercial FE software ABAQUS, and assigned with the linear brick element (C3D8) for the numerical simulations. The entire unit cell model used for the FE simulations consists of 53200 solid elements (Figure 1a).

In order to accomplish the FE simulations, the micro-mechanical (UD) material properties of the carbon-PPS representing the homogenized material properties of the impregnated yarn (Table 2) are derived from the individual elastic properties of the carbon fibre and PPS matrix using the Chamis [16] analytical homogenization formulas. The obtained homogenized micro-mechanical material properties are assigned to the yarn cross-sections in their local coordinate system to account for the yarn crimp in the FE model. In order to simulate the local strain behavior in the laminate inner layers, 3D PBCs $[6,17]$ are applied to the unit cell FE mesh. As explained in Part I, in order to calculate the local strains in the elastic regime and to compare with experimental fibre optic sensor results, an average tensile strain of $0.2 \%$ is applied to the unit cell in the warp yarn direction (Figure 1a) and the results are discussed in the current section.

The local strain pattern on the scale of a single unit cell with the matrix as well as on the reinforcement is shown in Figure 1(a,b). Figure 1c depicts the local longitudinal strain profile plotted over the length of the unit cell in the load carrying direction from one yarn crimp to the other as marked with the dotted line in Figure 1a. 
From Figure 1(a, c), it is evident that the maximum tensile strain $(0.27 \%)$ in the unit cell occurs at the edges of the weft yarn at the yarn crimp location. The minimum local strain $(0.17 \%)$ in the entire unit cell is detected in the resin pockets at the geometrical transition location between the yarn crimp (weft) to the straight yarn location (warp). Finally, along the straight portion of the load carrying warp yarn, the mean strain around $0.18-0.19 \%$ is observed. Comparison of the FE local strains with the FOS (Fibre Optic Sensor) results measured in the laminate inner layers (Table 3) shows good correlation starting from the maximum to the minimum values.

Based on the heuristic approach, it is assumed that the local strain values measured from the optical fibre sensor inside the laminate (maximum, minimum) belong to the same locations as observed in the unit cell FE analysis. Moreover, comparison of the experimental (surface) and numerical (3D PBCs-inside the laminate) local strain profiles (Figure 1c) shows that, quantitatively, the predicted FE local strain values are within the close limits of the experimental surface strain values. However, comparison of the experimental (Figure 3) and numerical strain spatial distribution (Figure 1a) indicates that there is a difference in the maximum and minimum strain locations. The obtained difference in the spatial strain distribution between the experiment and numerical simulations is manifested by a change in the local strain profiles (Figure 1c). The above obtained qualitative difference underscores the necessity for improvement in the unit cell FE procedure used for the surface local strain analysis. 
In order to understand the difference between computed (inner) local strain profile and the experimental local surface strain profiles (DIC), a unit cell stack should be developed with the internal yarn shifting (nesting) that is present in a textile laminate. Consequently, $\mathrm{BC}$ 's used for the FEA should be changed according to the $\mathrm{BC}$ 's that are prevailing on the composite laminate under the experimental tensile test. However, producing a unit cell stack with all shifting (nesting) details that are present in a textile laminate is practically not feasible. The above mentioned problem can be circumvented by creating different unit cell stacking configurations for the FE analysis as explained in $[13,18]$. Apart from the computation of the local strain profiles at various locations of the composite, different unit cell stack FE analyses provide an insight into the effect of internal yarn shifting (nesting) on the local surface strain pattern.

\subsection{Local strain analysis on the laminate traction free surface}

As explained in the previous section, for the calculation of local strain profiles in the elastic strain regime on the unit cell traction free surface, an average tensile strain of $0.5 \%$ is applied to the unit cell in the warp yarn direction. The results are discussed in the current section.

Initially, for the simulation of the surface strain profile, FE analysis is started with a single unit cell using in-plane periodic boundary conditions. Comparison of the FE local strain values with the DIC local strains at the average tensile strain of $0.5 \%$ (Figure $2 b$ ) 
shows that the single unit cell FE analysis predicts 50\% higher local strain at the yarn crimp location compared to the DIC results. The difference in the local strain values between the numerical and experimental results can be attributed to the large tension/bending coupling effects caused by the unrestricted yarn undulation in a single ply lamina [12]. However, FE (Figure 2a) and DIC (Figure 3) strain contours show that the maximum local strain occurs at the centre of the weft yarn at the yarn crimp location. Therefore, in order to keep the surface layer under traction free condition, and at the same time to provide the support in the form of adjacent layers in the unit cell thickness direction, investigation of the local surface strain analysis is accomplished by using the following unit cell stacks [13, 19].

- Unit cell stack with in-phase stacking

- Unit cell stack with step stacking

- Unit cell stack with out-of-phase stacking

In the in-phase stacking, unit cells are placed in such a way that the anticipated displacement at the yarn crimp location is compatible and in-phase [9] as shown by the arrows in Figure 4a. In contrast, for the out-of-phase stacking (Figure 4b) the anticipated displacement at the yarn crimp is not compatible and will act to reduce displacement of the weft yarn at the yarn crimp location. In case of step stacking, the yarn crimps of the unit cells are placed to form steps as shown in Figure 4c. 
In the above mentioned three unit cell stacks, in-phase and step stacking unit cell models are created using the 'WiseTex' software $[15,20]$. Where as the third model (out-ofphase stacking) is developed using python script ('Pyformex' [21]) by performing series of translational and rotational operations on the single unit cell FE mesh obtained from 'MeshTex'. Moreover, nodes at the joining faces of the unit cells are tied to each other so that the perfect bonding is assured between the unit cells.

Choosing four unit cells in the stack (Figure 4a-c) from the laminate of eight layers, FE analysis of the unit cell stack is accomplished using in-plane periodic boundary conditions [22]. In addition, symmetry boundary conditions are applied at the bottom xzsurface and the top xz surface is allowed to deform in the out-of-plane direction (Figure 4a). Using different unit cell stacks along with the above specified boundary conditions, FE simulation of the unit cell stacks is accomplished at $0.5 \%$ of the average tensile strain and results are presented here.

Comparison of the experimental (Figure 3) and numerical surface strain contours (Figure 4a-c) show that, in correlation with the DIC and the single unit cell (2D PBC) FE strain contours, in-phase unit cell stack (Figure 4a) predicts the maximum strain at the centre of the weft yarn at the yarn crimp location. Moreover, it is also evident that the change in the unit cell stack and the applied BC's causes the shift in the maximum strain location from centre to the edge of the weft yarn for the other two unit cell stacks (Figure $4 \mathrm{~b}, \mathrm{c}$ ). 
Figure $5(\mathrm{a}, \mathrm{b})$ compares the experimental strain profiles with the numerical longitudinal surface strain profiles obtained from the different unit cell stacks. As shown in Figure 5a, the variation in the numerical local strains on the unit cell traction free surface is summarized as follows:

- Depending on the unit cell stacking and boundary conditions used for the FE simulation, the maximum strain location on the weft yarn at the yarn crimp location changes from the centre to the edge. Comparison of local longitudinal strain profiles computed from different unit cell stacks (Table 3) gives the following order of local strain at the yarn crimp location (first part): single unit cell $(2 \mathrm{D}$ PBC $)>$ in-phase stacking $>$ step stacking $>$ single unit cell with $3 \mathrm{D}$ PBC $>$ out-of-phase stacking.

- The second part of the strain profile is associated with the minimum strain value adjacent to the yarn crimp location. The obtained minimum strain values from the different unit cell stacks as well the experimental techniques show very good correlation.

- The final part of the strain profile belongs to the straight portion of the load carrying warp yarn, whose value from all the measurements varies in between $0.48-0.53 \%$. 
Figure $5 \mathrm{c}$ presents the comparison between the experimental and numerical local transverse strain, which shows good correlation for all unit cell stacks. As observed in the experiments, meso-FE simulations predict the positive transverse strain on the weft yarn at the yarn crimp location. And the resin pockets as well as the straight position of the warp yarns sustain the compressive transverse strain due to the Poisson's effect. Moreover, it should be noted that each yarn in the above mentioned unit cell stacks contains four or more elements over its cross section. In-phase and step stacking unit cell models contain 78500 elements, where as the out-of-phase model contains 319200 elements. Regarding the effect of mesh density on the local strain behavior, Lomov et al. [2] concludes that the mesh density shows minor influence on the local strain behavior. Also, from the investigation of the effect of mesh density on the unit cell local stress behavior [14] it appears that when the yarn contains four or more elements over its crosssection, the local stress behaviour converges to the same value.

In the process of investigating the local stress components that are responsible for the sequential weft yarn damage in the carbon-PPS 5-harness satin weave composite, local stress analysis is conducted. From the cumulative AE energy curve and the microscopic damage analysis of the carbon-PPS satin weave composite, it was concluded that the weft yarn damage in the plies of a satin weave composite is a sequential process [23]. However, experimental local strain analysis (Part I) concludes that there is hardly any influence of the internal yarn shifting (nesting) on the local longitudinal strain behavior. 
In order to investigate the stress component that causes the sequential damage in the satin weave composite, local stress analysis is conducted anond the results are discussed in the current sect. In correlation with the experimental observations of the local longitudinal strain, the local longitudinal stress analysis in the laminate inner layers as well as on the unit cell traction free surface shows very good correlation (Figure 6a). However, at the applied average tensile strain of $0.5 \%$, there is a difference of $23 \%$ in the local transverse stress for weft yarns at the yarn crimp location between the infinite laminate and the finite laminate with out-of-phase stacking(Figure 6b).

\section{CONCLUSION}

In the previous paper (Part I), an experimental procedure has been introduced for the analysis of local strain behavior in the plies of a thermo-plastic carbon-PPS satin weave composite under uni-axial static tensile load. In order to understand the influence of ply stacking (nesting) on the local strain behavior of the satin weave composite, meso-FE simulations are performed using different unit cell stacks. Comparison of the experimental and numerical results leads to the following conclusions:

- Local strain profiles are sensitive to the unit cell geometrical model as well as the applied boundary conditions to the unit cell. 
- Comparison of the experimental and numerical surface strain results implies that, by restricting the yarn undulation effects using 3D PBCs or shifting of the beneath layers in the unit cell stack, quantitatively, the numerical surface strain results approach to the experimental results. However, the maximum strain locations obtained from FE simulations differ from those of the experimental strain contours.

- From the local stress analysis on different unit cell models, it is evident that the weft yarn transverse stress is sensitive to the ply position in the laminate along with the out-of-plane shear stress [14]. The variation in the local transverse stress at the yarn crimp location causes the sequential weft yarn damage according to the ply position in the laminate.

As a summary, the present communication emphasizes the effect of internal yarn shifting (nesting) on the local strain behavior of a satin weave composite. To predict the FE local surface strains both qualitatively and quantitatively comparable to experimental results, unit cell geometry with maximum ply shift should be developed. However, it is a tedious process to develop a full scale unit cell stack with the detailed internal yarn nesting for the computational purpose. As a consequence, it is imperative to develop the above explained unit cell stacks to obtain an insight into the maximum and minimum limits for the surface local strain profiles as well as the variation in local strain contours. 


\section{ACKNOWLEDGEMENTS}

The authors would like to acknowledge the FWO - Vlaanderen for the financial support through the project G.0233.06H. The help of laboratory staff of the department of the MTM - Kris van der Staey and Johan Vanhuist is gratefully acknowledged. The authors also express their gratitude to 'Ten Cate' for supplying the composite plates. The authors also want to acknowledge the assistance of Dmitry Ivanov. 


\section{REFERENCES}

1. Potluri, P., Young, R. J., Rashed, K., Manan, A. Meso-scale strain mapping in UD woven composites. Composites Part A: Applied Science and Manufacturing, 2009. 40(12): p. 1838-1845.

2. Lomov, S.V., Ivanov, D S., Verpoest, I., Zako, M., Kurashiki, T., Nakai, H., Molimard, J., Vautrin, A. Full-field strain measurements for validation of mesoFE analysis of textile composites. Composites Part A: Applied Science and Manufacturing, 2008. 39(8): p. 1218-1231.

3. Summerscales, J., Russel, P.M. Observations on the fibre distribution and fibre strain in a woven fabric reinforcement. Advanced composite letters 2004. 23 No.3, 2004.

4. Anzelotti, G., Nicoletto, G., Riva, E. Mesomechanic strain analysis of twill-weave composite lamina under unidirectional in-plane tension. Composites Part A: Applied Science and Manufacturing, 2008. 39(8): p. 1294-1301.

5. Nicoletto, G., G. Anzelotti, and E. Riva, Mesoscopic strain fields in woven composites: Experiments vs. finite element modeling. Optics and Lasers in Engineering. 47(3-4): p. 352-359.

6. Lomov, S.V., Ivanov, D.S., Verpoest, I., Zako, M., Kurashiki, T., Nakai, H., Hirosawa, S. Meso-FE modelling of textile composites: Road map, data flow and algorithms. Composites Science and Technology, 2007. 67(9): p. 1870-1891.

7. Ivanov, D.S., Ivanov, S., Lomov, S.V., Verpoest, I. Strain mapping analysis of textile composites. Optics and Lasers in Engineering. 47(3-4): p. 360-370

8. Hale, R.D., An experimental investigation into strain distribution in 2D and 3D textile composites. Composites Science and Technology, 2003. 63(15): p. 21712185.

9. Carvalho, N.V., Pinho, S.T., Robinson, P. Compressive failure of 2D woven composites. ICCM-17 Conference proceedings, 2009.

10. Owens, B.C., Whitcomb, J.D., Varghese, J. Effect of Finite Thickness and Free Edges on Stresses in Plain Weave Composites. 2009. p. 0021998309347571.

11. Ivanov, D.S., Lomov, S. V., Ivanov, S., Verpoest, I. Stress distribution in outer and inner plies of textile laminates and novel boundary conditions for unit cell analysis. Composites Part A: Applied Science and Manufacturing. 41(4): p. 571580.

12. Lee, J.-R., Molimard, J., Vautrin, A, and Surrel, Y. Digital phase-shifting grating shearography for experimental analysis of fabric composites under tension. Composites Part A: Applied Science and Manufacturing, 2004. 35(7-8): p. 849859.

13. Ito, M., Chou, T.-W. Elastic moduli and stress field of plain-weave composites under tensile loading. Composites Science and Technology, 1997. 57(7): p. 787800 . 
14. Daggumati, S., Van Paepegem, W., Degrieck, J., Xu, J., Lomov, S. V., Verpoest, I. Local damage in a 5-harness satin weave composite under static tension: Part II - Meso-FE modelling. Composites Science and Technology. 70(13): p. 19341941.

15 Verpoest, I. and S.V. Lomov, Virtual textile composites software WiseTex: Integration with micro-mechanical, permeability and structural analysis. Composites Science and Technology, 2005. 65(15-16): p. 2563-2574.

16. Chamis, C.C. Mechanics of Composite Materials Past, Present, and Future. NASA Technical Memorandum 100793, 1984.

17. Whitcomb, J.D., Chapman, C.D., and Tang, X. Derivation of Boundary Conditions for Micromechanics Analyses of Plain and Satin Weave Composites. 2000. p. 724-747.

18. Le Page, B.H., Guild, F. J., Ogin, S. L., Smith, P. A. Finite element simulation of woven fabric composites. Composites Part A: Applied Science and Manufacturing, 2004. 35(7-8): p. 861-872.

19. WOO, K., and Suh, Y.W., Phase shift effect on the stress distribution for satin weave composites. Journal of Composite Materials, 2001. Vol. 36, No. 03/2002.

20. Lomov, S.V., Verpoest, I., Peeters, T., Roose, D., Zako, M. Nesting in textile laminates: geometrical modelling of the laminate. Composites Science and Technology, 2003. 63(7): p. 993-1007.

21. Bagger, A., Verhegghe, B., Hertz, K.D. Modeling plate shell structures using pyFormex. Proceedings of the International Association for Shell and Spatial Structures (IASS) Symposium, Valencia, 2009.

22. Zako, M., Uetsuji, Y., Kurashiki, T., Finite element analysis of damaged woven fabric composite materials. Composites Science and Technology, 2003. 63(3-4): p. 507-516.

23. Daggumati, S., De Baere, I., Van Paepegem, W., Degrieck, J., Xu, J., Lomov, S. V., Verpoest, I. Local damage in a 5-harness satin weave composite under static tension: Part I - Experimental analysis. Composites Science and Technology. 70(13): p. 1926-1933. 
Table 1. Input data for the unit cell geometrical modeler software 'WiseTex'.

\begin{tabular}{|c|c|c|}
\hline \multicolumn{3}{|c|}{ WiseTex input data at fabric level } \\
\hline Property & 5 harness satin weave warp & 5 harness satin weave weft \\
\hline Yarn & 20 & 198 tex \\
\hline Number of measurements & $1.31 \pm 0.01$ & 20 \\
\hline Yarn width $(\mathrm{mm})$ & $0.162 \pm 0.01$ & $0.161 \pm 0.06$ \\
\hline Yarn thickness $(\mathrm{mm})$ & $1.50 \pm 0.04$ & $1.49 \pm 0.07$ \\
\hline Yarn spacing $(\mathrm{mm})$ & WiseTex input data at fibre level \\
\hline \multicolumn{2}{|c|}{198} \\
\hline TEX $(\mathrm{g} / \mathrm{km})$ & 3000 \\
\hline Yarn filament count & 0.007 \\
\hline Filament diameter $(\mathrm{mm})$ & \multicolumn{2}{|c|}{1.75} \\
\hline Carbon fibre density $\left(\mathrm{g} / \mathrm{cm}^{3}\right)$ & \\
\hline
\end{tabular}

Table 2. $\quad$ T300 JB carbon fibre, PPS elastic and strength properties.

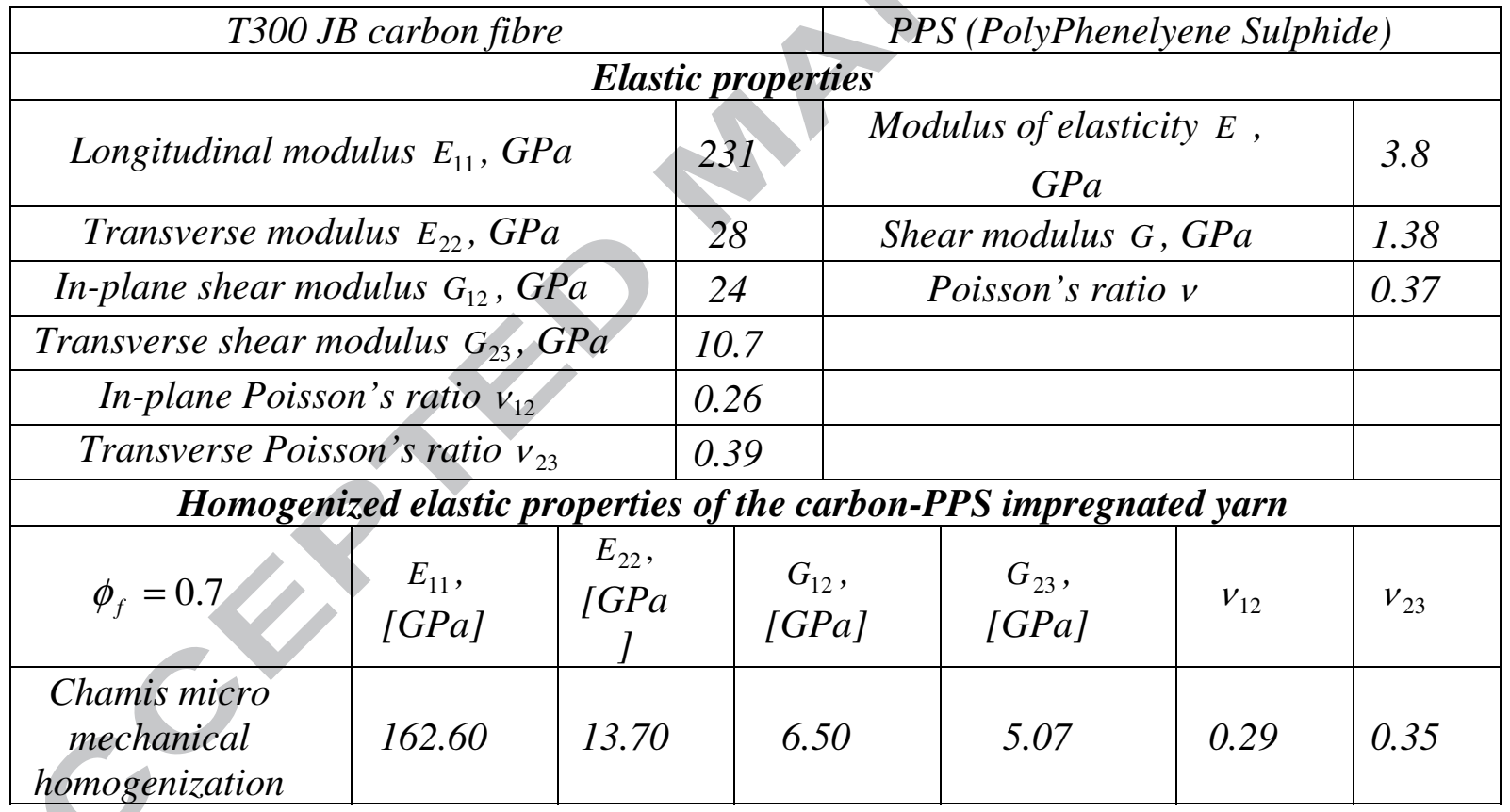


Table 3 Comparison of the local strain values - experiment vs. numerical simulations.

\begin{tabular}{|c|c|c|c|c|}
\hline & \multicolumn{2}{|c|}{ Inside the laminate } & \multicolumn{2}{|c|}{ Laminate surface } \\
\hline & $\operatorname{Max}, \%$ & $\operatorname{Min}, \%$ & $\operatorname{Max}, \%$ & Min, \% \\
\hline $\begin{array}{c}F B G \text { 's -strain inside the } \\
\text { laminate }-0.2 \%\end{array}$ & 0.25 & 0.16 & $-N A-$ & \\
\hline $\begin{array}{c}\text { Single unit cell -3D PBC } \\
0.2 \%\end{array}$ & 0.27 & 0.17 & $-N A-$ & \\
\hline $\begin{array}{c}\text { Single unit cell }-3 D P B C \\
0.5 \%\end{array}$ & 0.65 & 0.47 & $-N A-$ & $-N A-$ \\
\hline $\begin{array}{c}\text { LIMESS (DIC) - Surface } \\
\text { strain } 0.5 \%\end{array}$ & $-N A-$ & $-N A-$ & $0.58-0.62$ & $0.43-0.46$ \\
\hline $\begin{array}{c}\text { Single unit cell }-2 D P B C \\
0.5 \%\end{array}$ & $-N A-$ & $-N A-$ & & $0.1 \%$ \\
\hline $\begin{array}{l}4 \text { Unit cells - out-of- } \\
\text { phase stacking } 0.5 \%\end{array}$ & $-N A-$ & $-N A-$ & 0.65 & 0.44 \\
\hline $\begin{array}{l}4 \text { Unit cells }- \text { step } \\
\text { stacking } 0.5 \%\end{array}$ & $-N A-$ & & $0.65-0.0 .69$ & $0.32-0.44$ \\
\hline $\begin{array}{l}4 \text { Unit cells - in-phase } \\
\text { stacking } 0.5 \%\end{array}$ & $-N A-$ & & 0.73 & 0.35 \\
\hline
\end{tabular}


a)

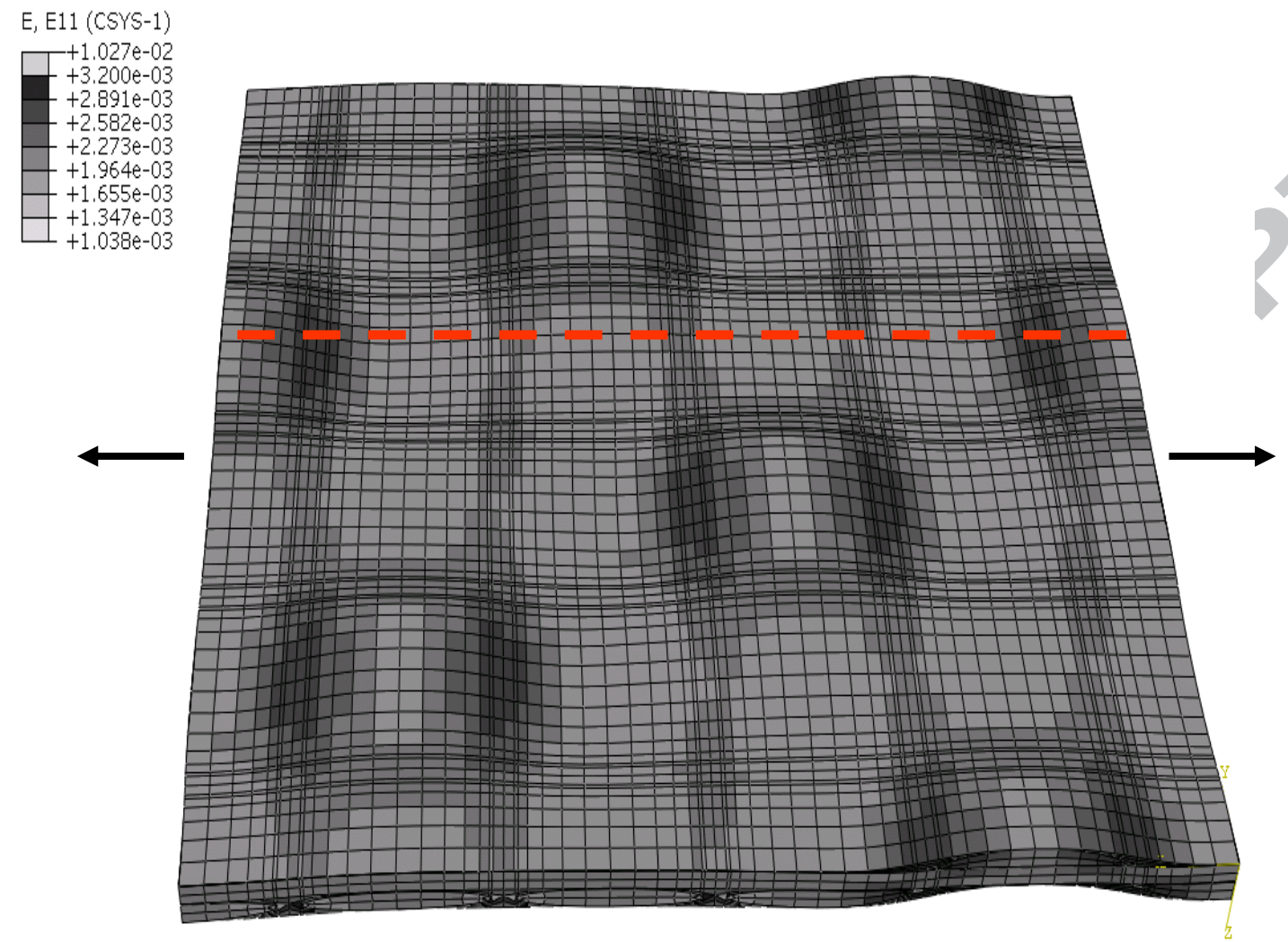

b)

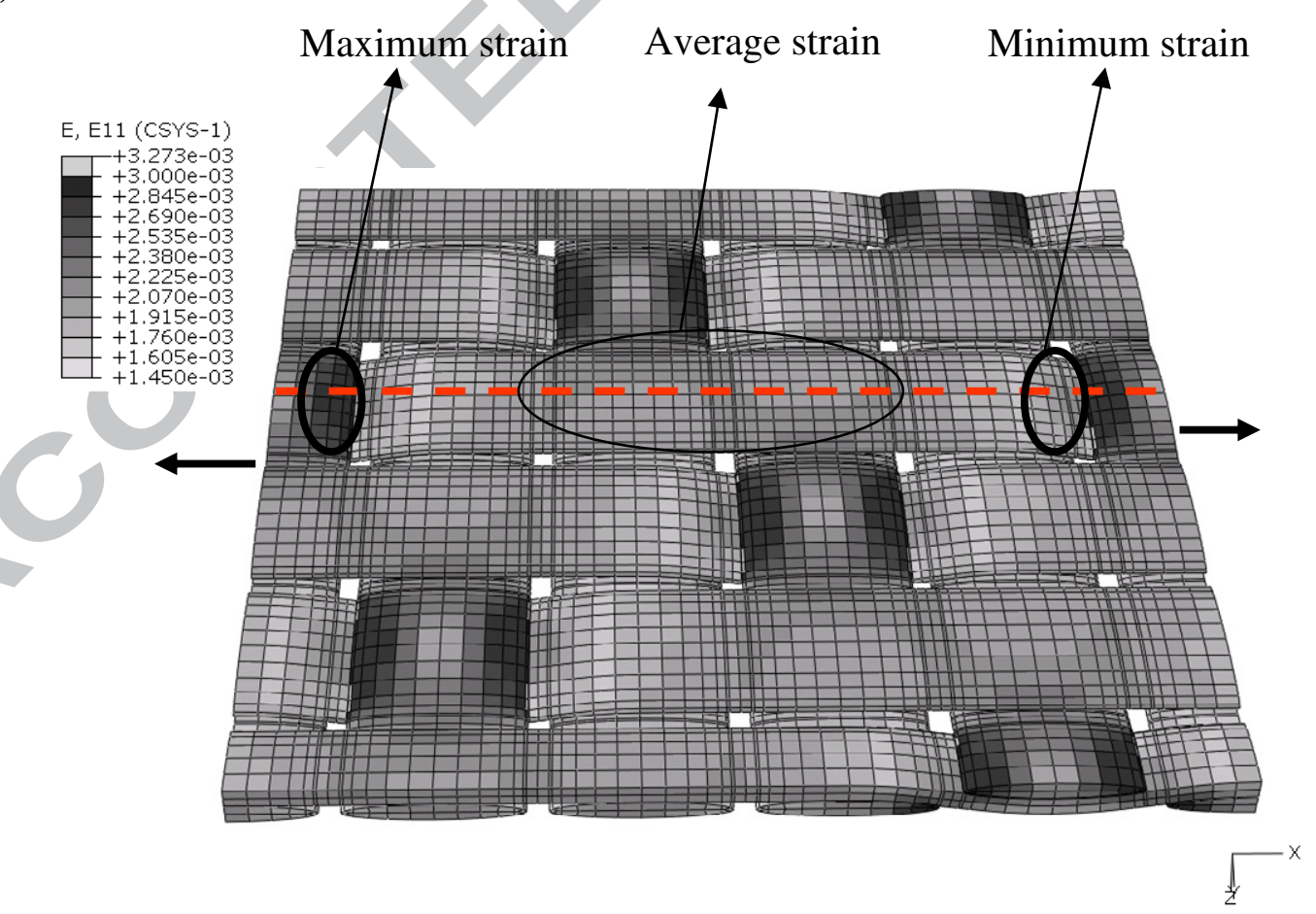


c)
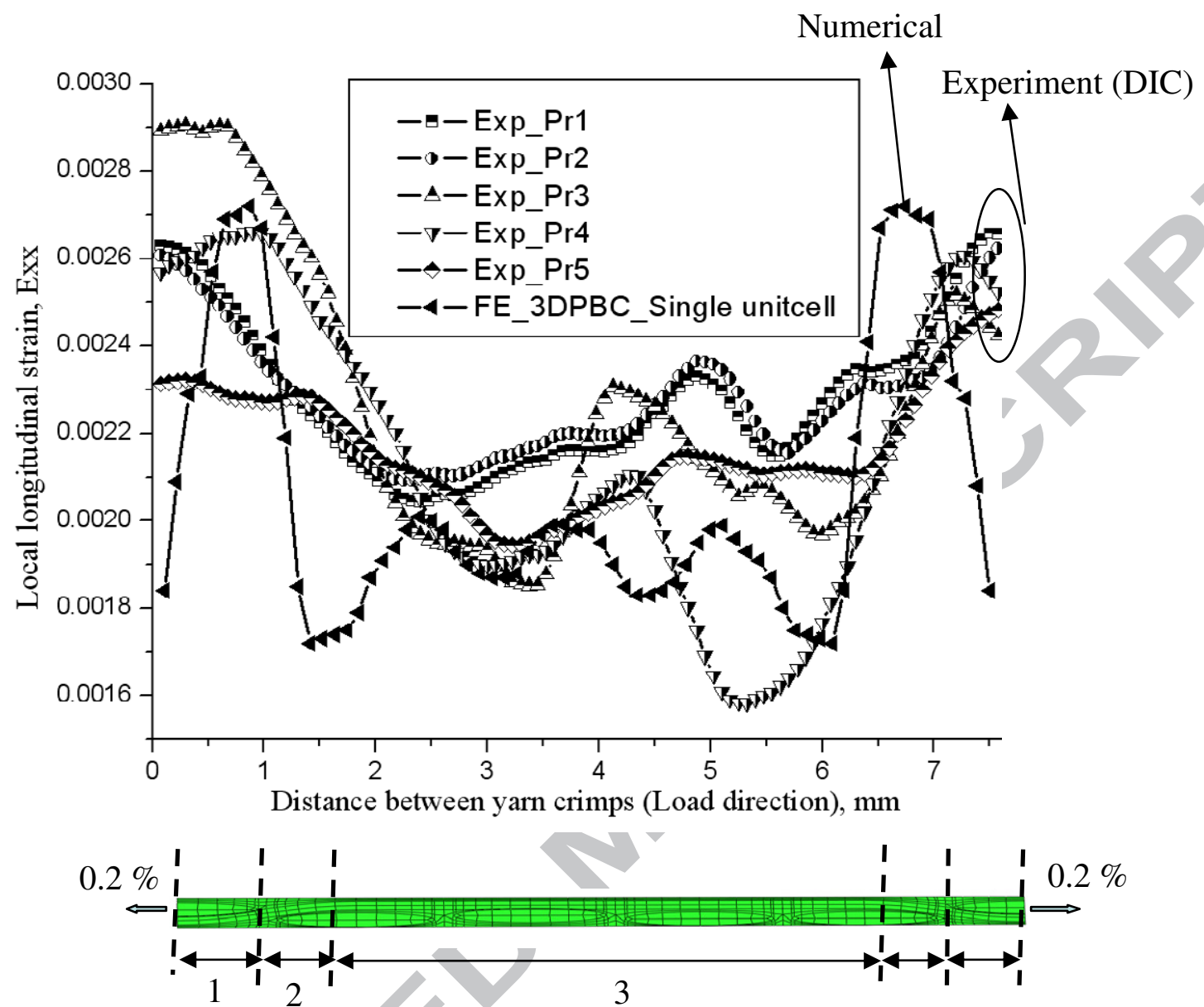

Figure 1. Single unit cell FE analysis with infinite laminate boundary conditions: a) longitudinal strain contours on the matrix surface; b) longitudinal strain contours on the reinforcement; c) comparison of the experimental (surface) and numerical (inner) local strain profiles at $<0.2 \%>$. 
a)

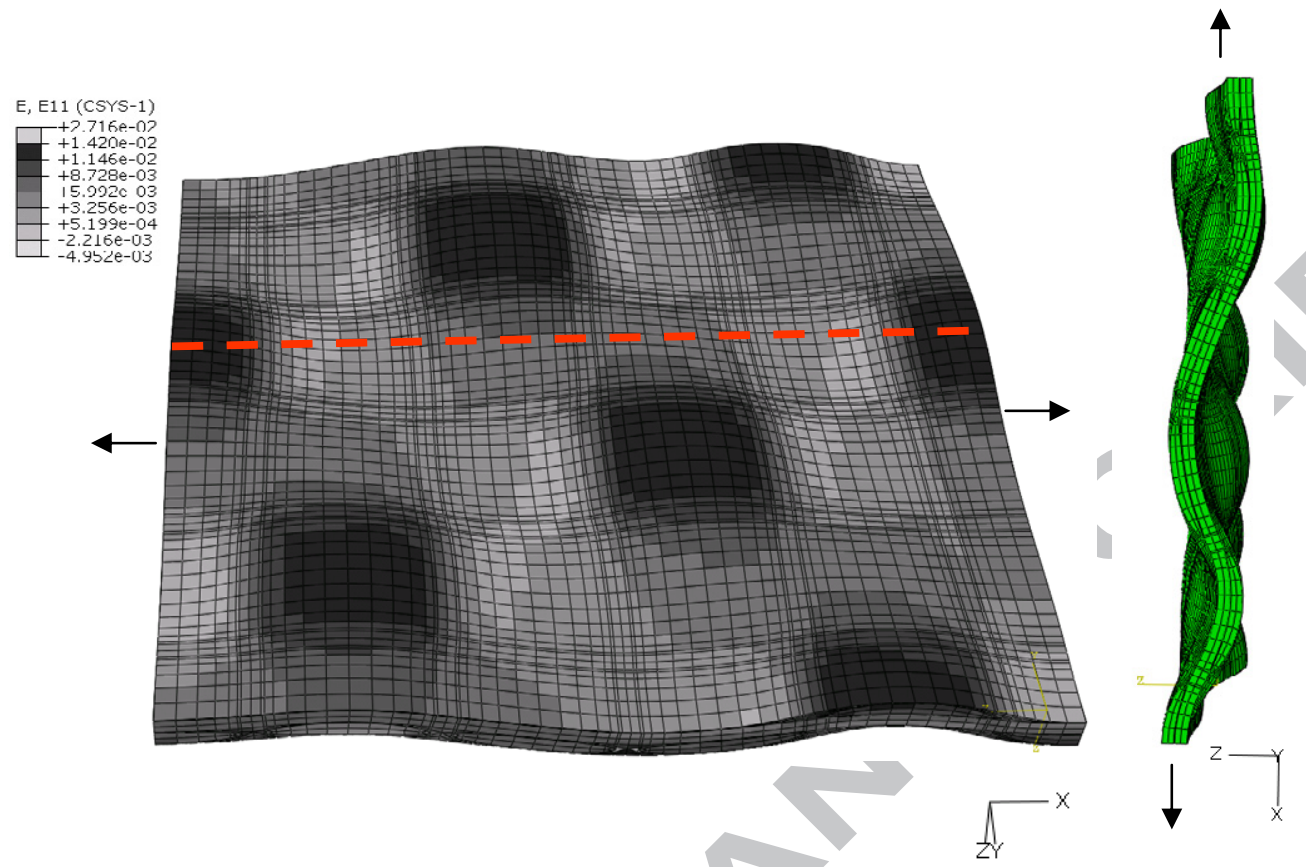

b)

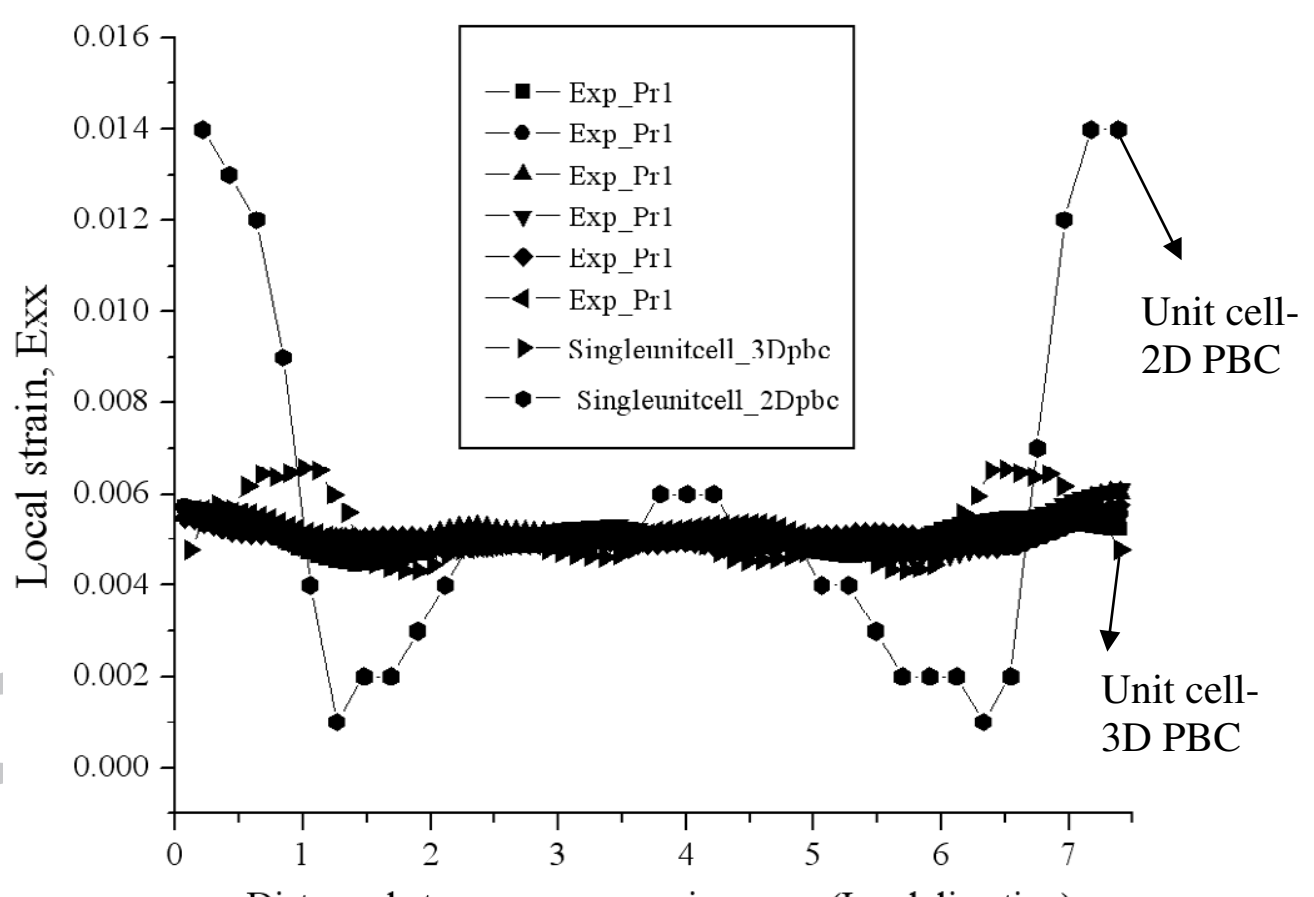

Distance between one yarn crimp, mm (Load direction)

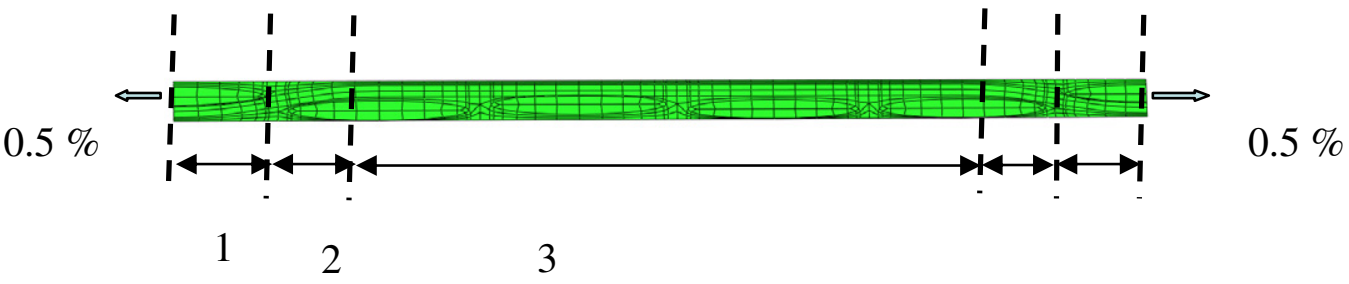


Figure 2. Single unit cell FE analysis with in-plane PBC: a) strain contour on the unit cell surface; b) comparison of the experimental and numerical strain profiles at $<0.5 \%>$

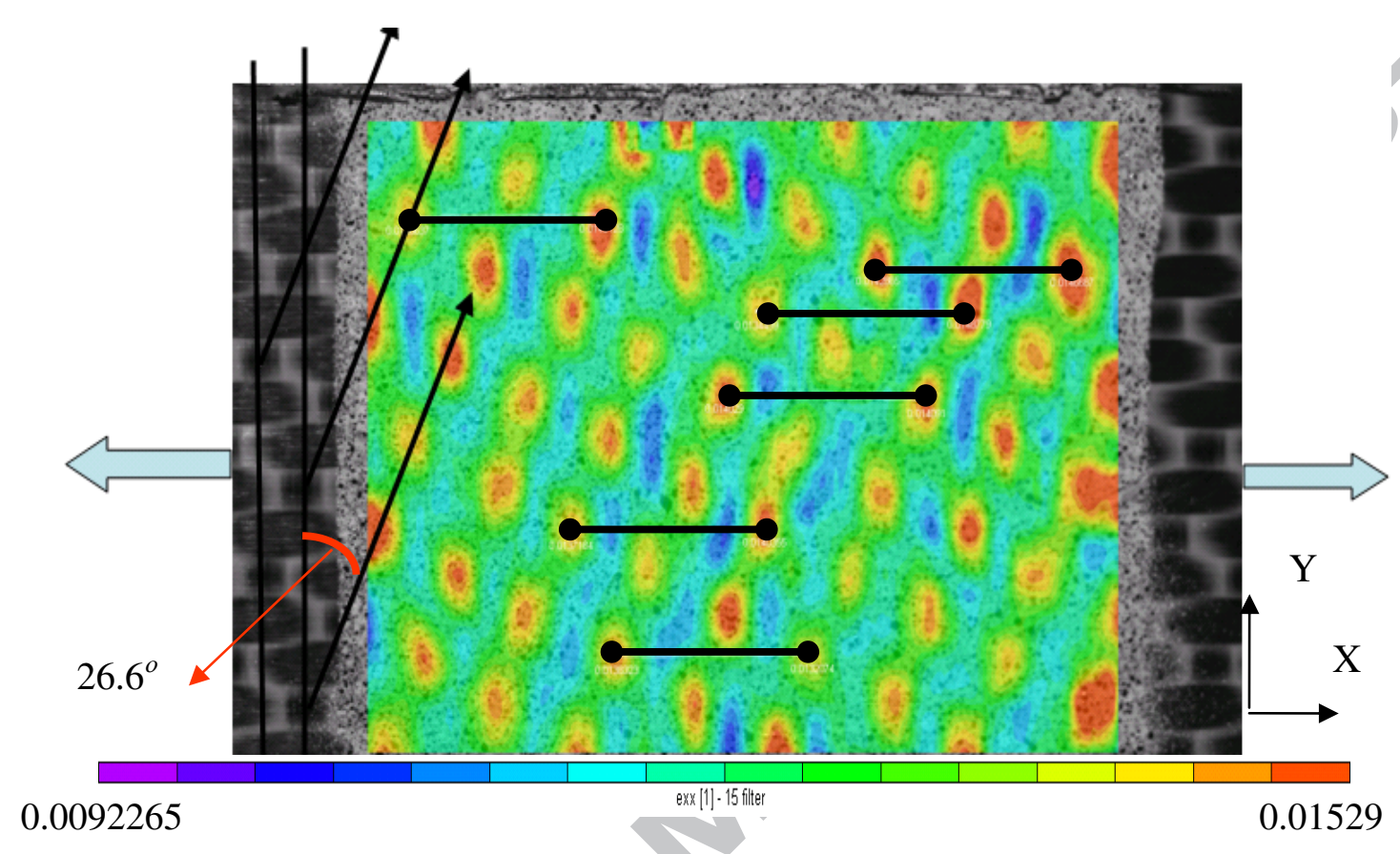

Figure 3 Surface strain profile obtained from DIC at the average tensile strain of $1.19 \%$. 
a)

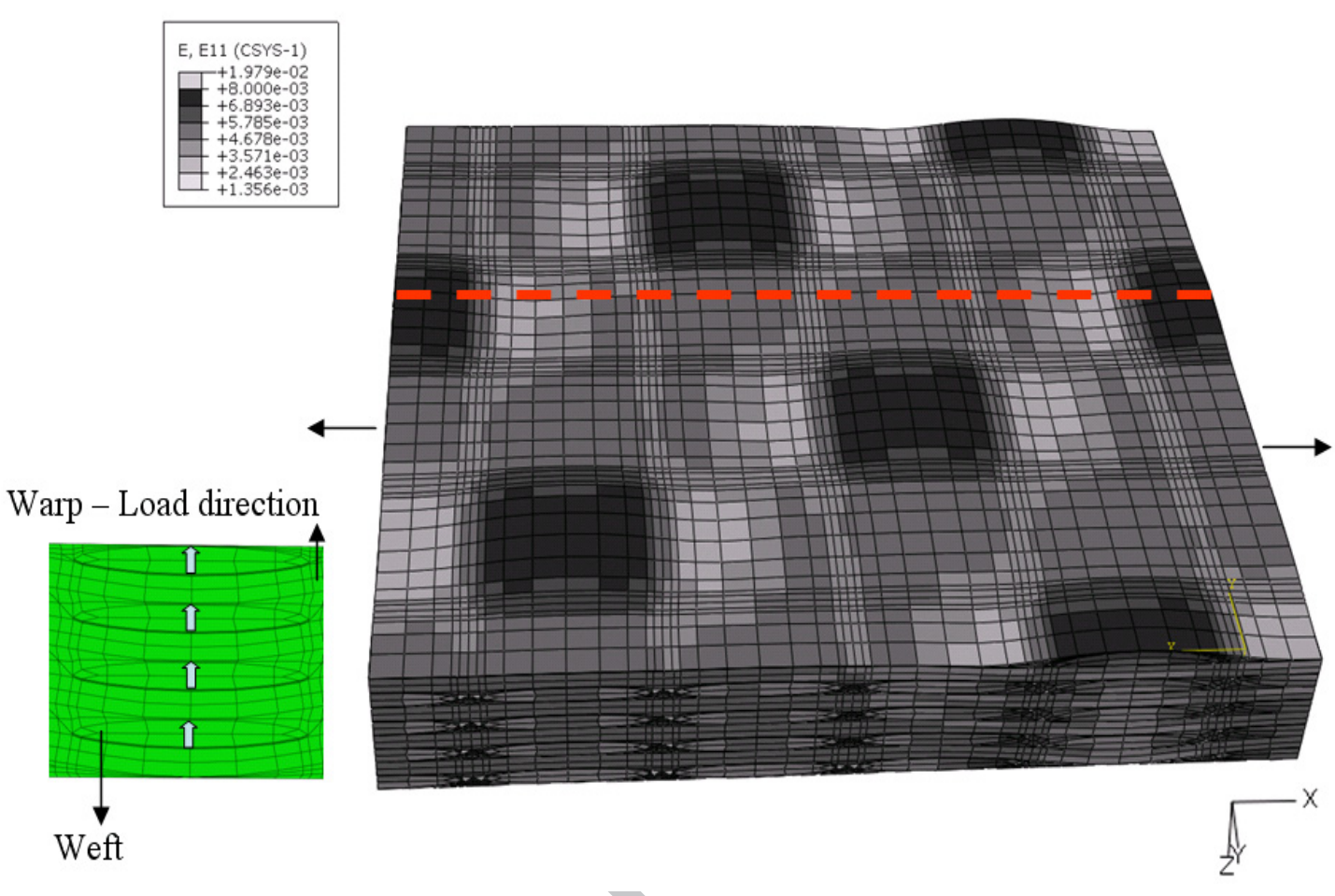

b)

E, E11 (CSYS-1)

(Avg: 75\%)

$+1.959 \mathrm{e}-02$
$+7.000 \mathrm{e}-03$
$+6.222 \mathrm{e}-03$

$+5.444 \mathrm{e}-03$

$+4.667 \mathrm{e}-03$

$+3.889 \mathrm{e}-03$

$+3.111 \mathrm{e}-03$

$+2.333 \mathrm{e}-03$

$+1.556 \mathrm{e}-03$

$+7.778 \mathrm{e}-04$

$+0.000 \mathrm{e}+00$

$+0.000 \mathrm{e}+00$
$-1.087 \mathrm{e}-02$
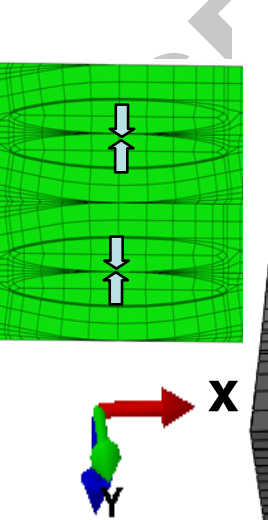

Z

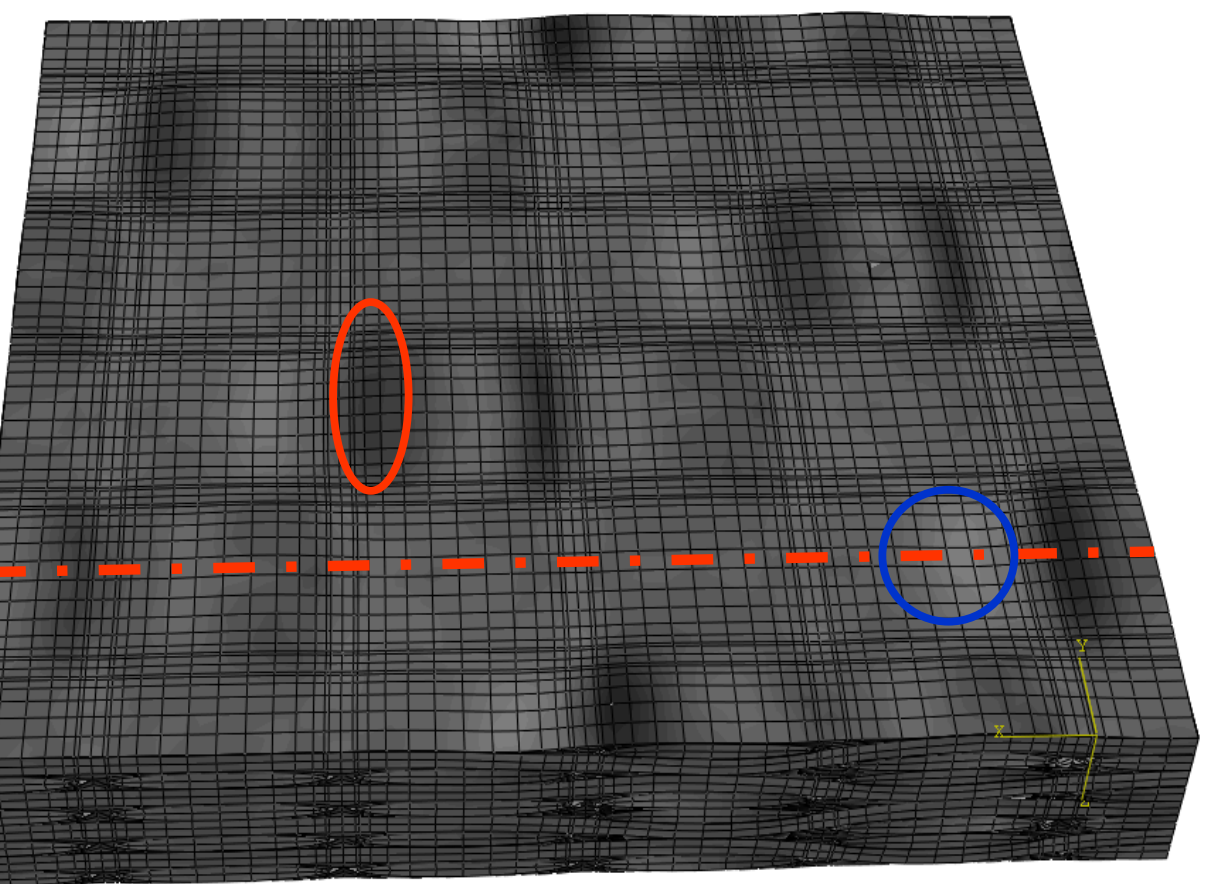


c)

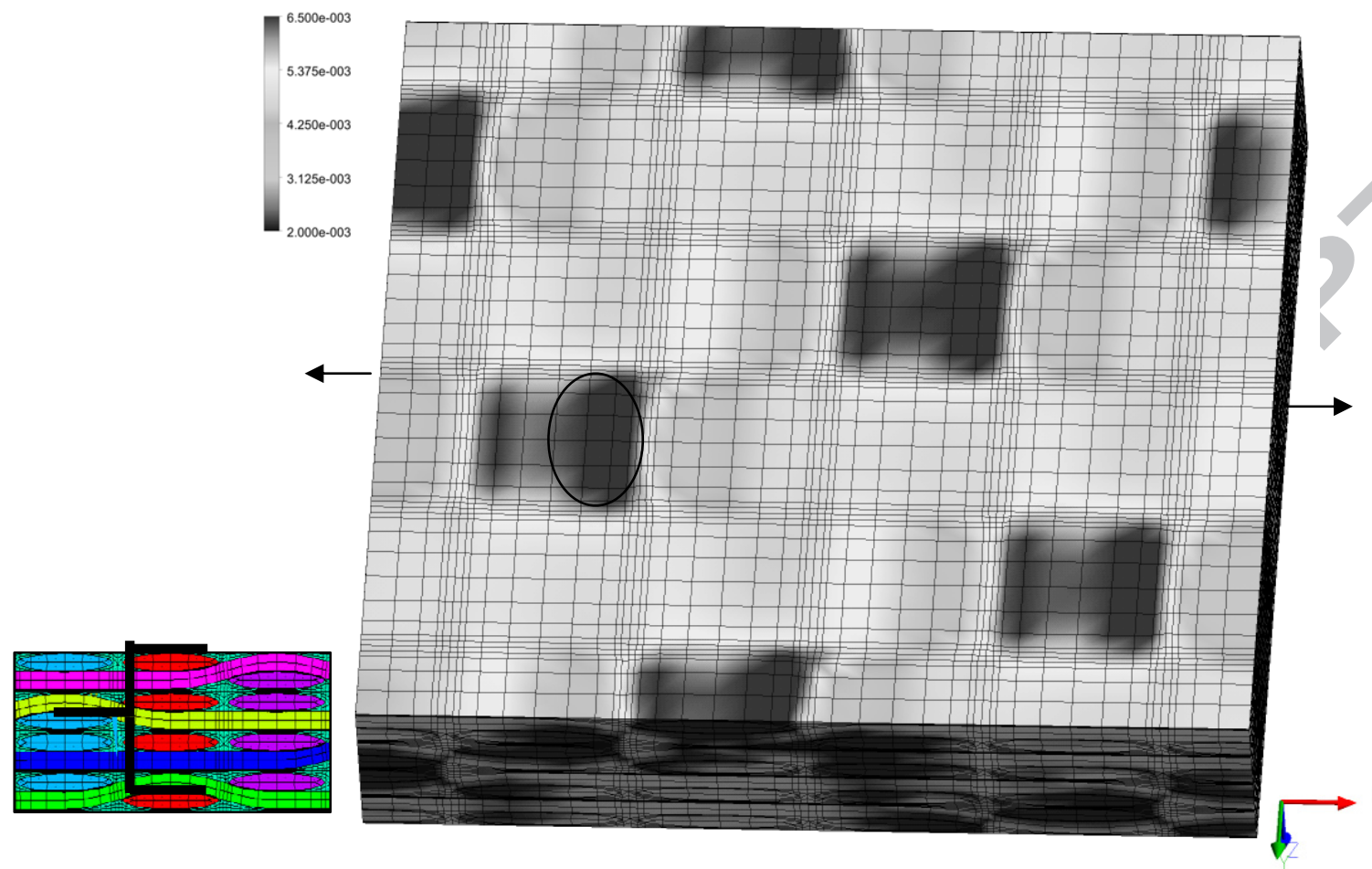

Figure 4. Unit cell stack FE analysis at $<0.5 \%>$ : a) 4 unit cells with in-phase stacking; b) 4 unit cells with out-of-phase stacking; c) 4 unit cells with step stacking (2D PBC and Z-symmetry at bottom surface, top surface is traction free). 
a)

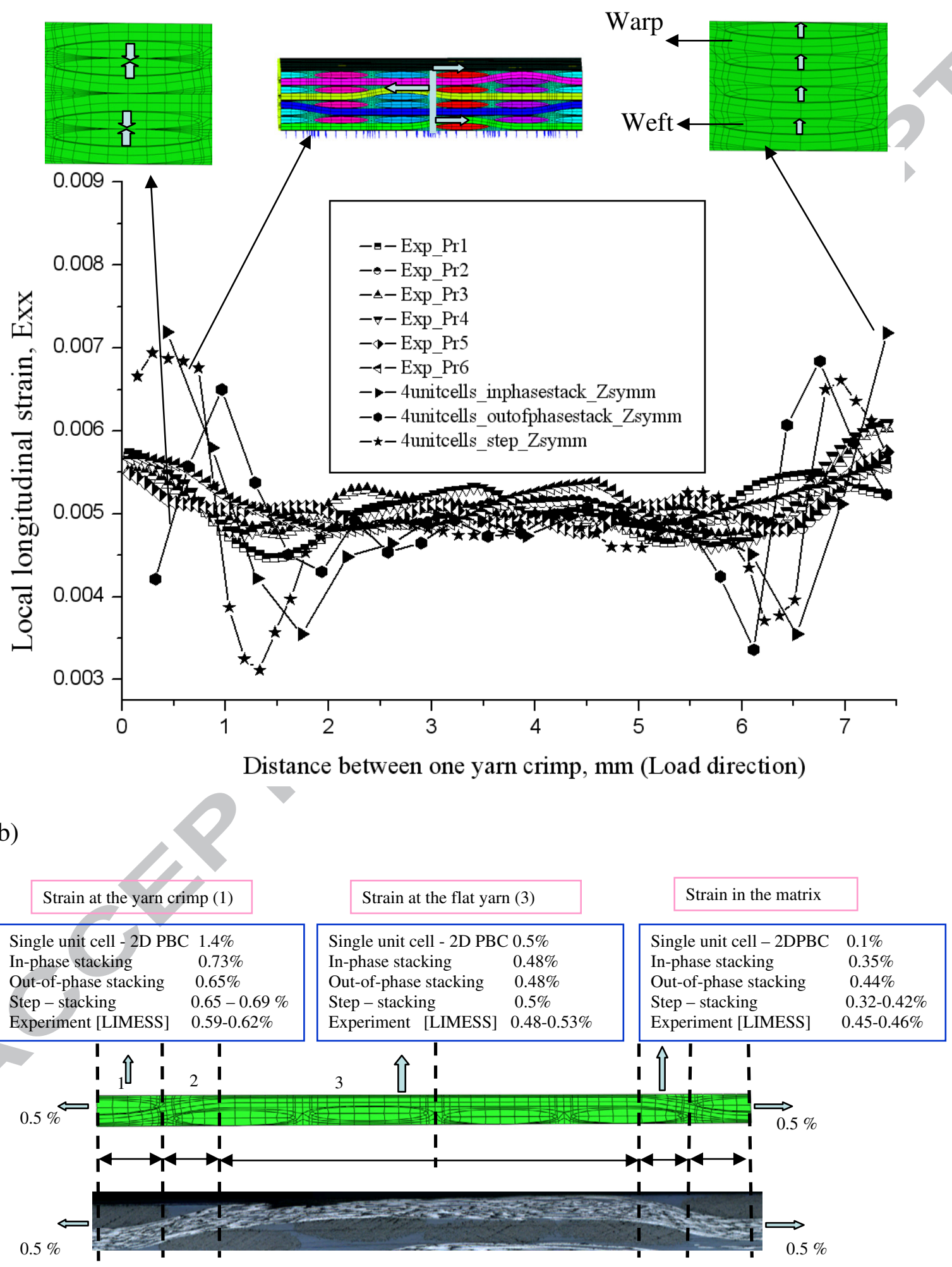


c)

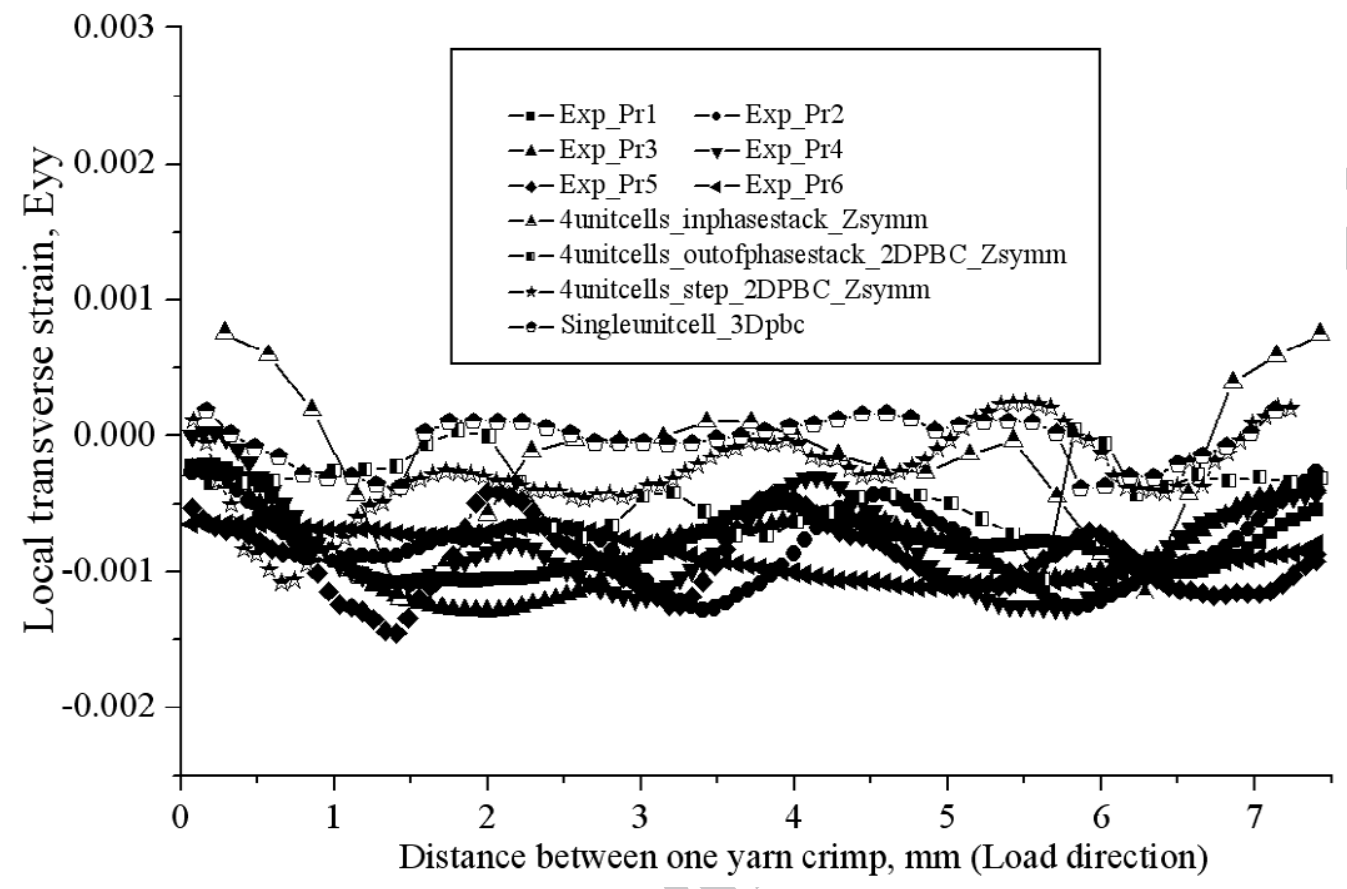

Figure 5. Comparison of experimental and numerical local strain profiles at $0.5 \%$ average tensile strain: a, b) Comparison of longitudinal local strain profiles \& strain locations; c) Comparison of transverse local strain profiles experiment vs. simulation. 
a)

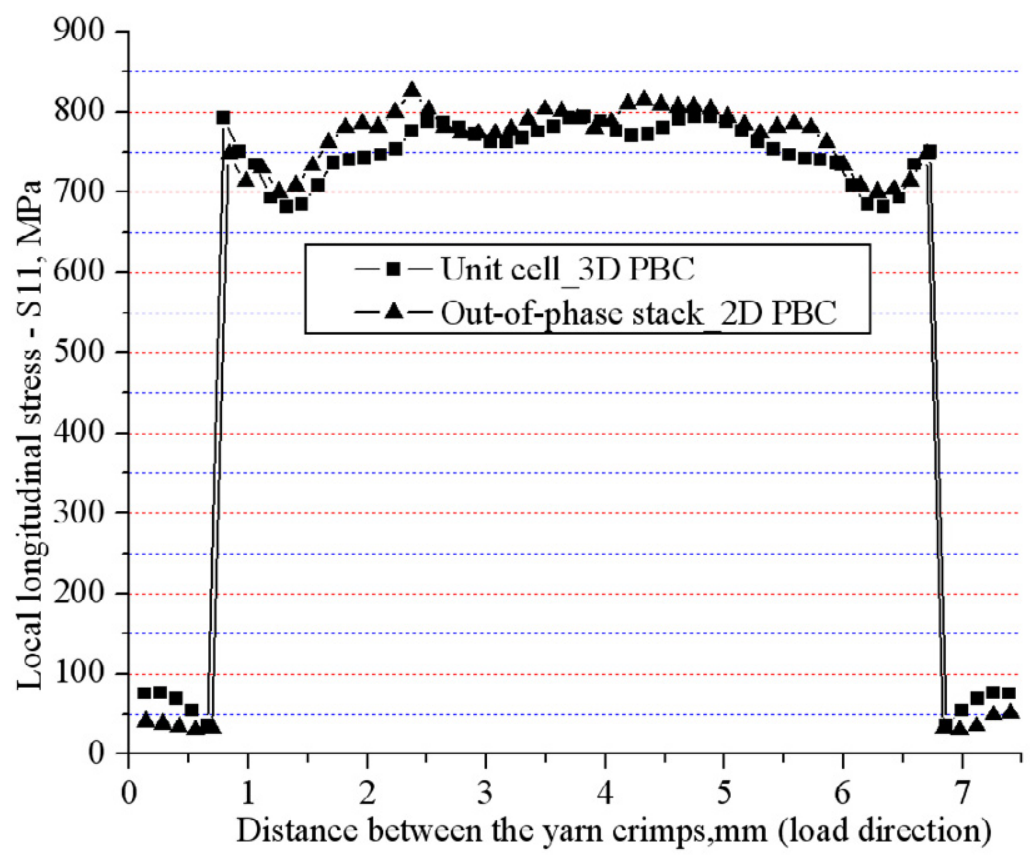

b)
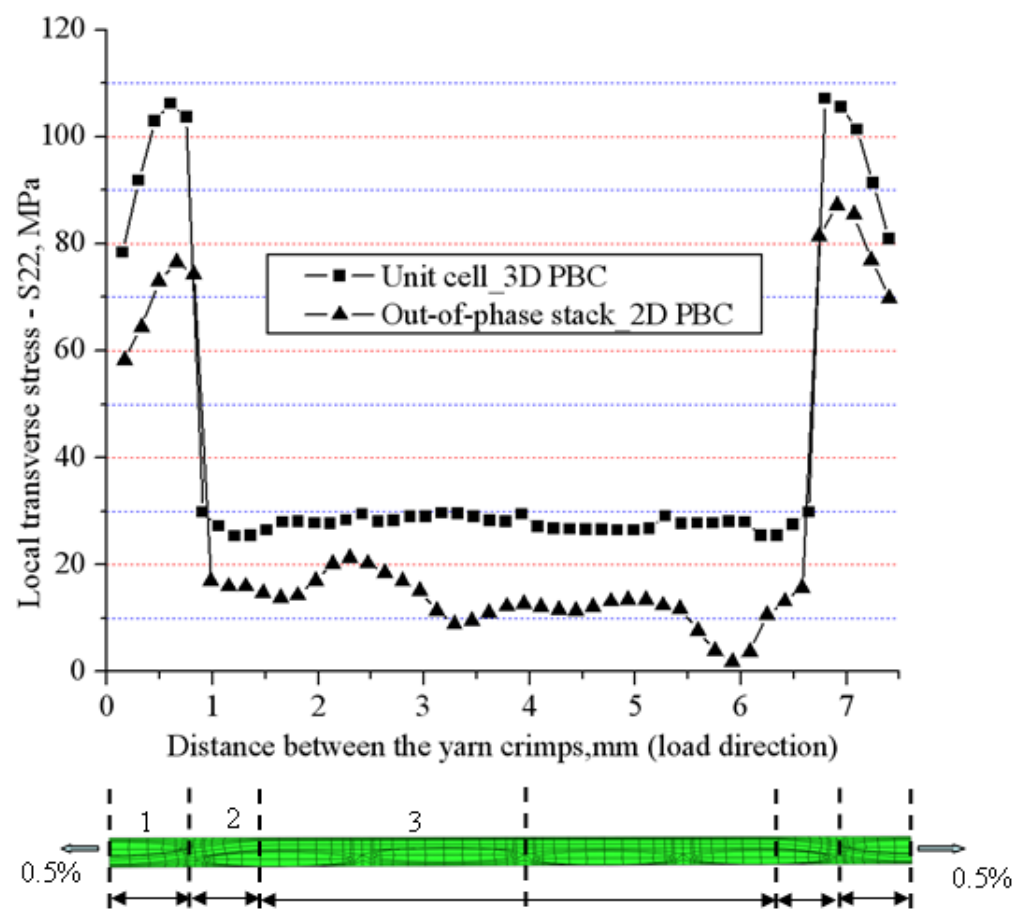

Figure 6. Comparison of the local stress profiles at an average strain of $0.5 \%$ strain: a) local longitudinal stress profiles; b) local transverse stress profiles. 